\title{
ENVIRONMENTAL RISKS FOR GEMSTONE MINERS WITH REFERENCE TO MERELANI TANZANITE MINING AREA, NORTHEASTERN TANZANIA
}

\author{
EP Malisa and CP Kinabo, \\ Department of Geology, University of Dar es Salaam, \\ P.O. Box 35052, Dar es Salaam, Tanzania. \\ E-mail: pausenelias@yahoo.com
}

\begin{abstract}
Artisanal and small-scale gemstone miners are the workers with the highest health risk exposure in Tanzania. Gemstone mining at Merelani tanzanite mines which has gone to depths of $100 \mathrm{~m}$ or more in narrow straight and inclined shafts, underground artisanal miners work under a very harsh environment. Tanzanite deposits are located within sheared zones, lying along a deepseated Lelatema fault zones. Rocks along these zones which are mainly graphitic and or/gypsumbearing gneisses surrounded by limestone are soft, fractured and strongly weathered. Poor mining techniques, lack of geological background, chronic shortage of capital, and the lack of awareness on environmental pollution in the shafts have led to health and safety problems. In deep mines such as Merelani tanzanite mine, where the rocks are graphitic $(C$-rich), existence of poisonous gases is common. Dust exposure during drilling, blasting and shovelling indicates high average levels of overall respirable dust $15.5 \mathrm{mg} / \mathrm{m}^{3}$ whereby respirable quartz and graphite are $2.4 \mathrm{mg} / \mathrm{m}^{3}$ and $1.5 \mathrm{mg} / \mathrm{m}^{3}$, respectively. The total amount of dust is $28.4 \mathrm{mg} / \mathrm{m}^{3}$. Supply of air (oxygen) to such depths by using small compressors is unreliable and inadequate, since they sometimes fail or deliberately are switched off. Further, lack of adequate ventilation for eliminating the toxic gases after blasting results in particles hazardous to the miners. Exposure to dust mixed with graphite; quartz and micas particles are harmful and may cause lung cancers or development of chronic silicosis. The workers and mine owners are supposed to adhere to mining rules, regulations and code of practice. Mines must be properly ventilated and back filling is necessary in mined out pits. Most of artisanal gemstone mining in Tanzania is substandard which results in fatal accidents. It is recommended that proper mining methods should be adhered to following the code of practice issued by the Ministry of Energy and Minerals.
\end{abstract}

\section{INTRODUCTION}

Although small-scale mining in developing countries provides employment and source of income, health hazards and risks are very high. These mines are labour intensive, with low-level mechanisation, and the sub sector employs men, women and children. In Merelani tanzanite mine, there are more than 3000 underground miners mostly young boys working in shifts down to 100 meters. The aerial coverage for individual tunnels are about $1.5-2 \mathrm{~m}^{2}$ and no other machinery is used except old compressors, pneumatic drills, air blowers, generators, jackhammers, hosepipes and explosives. After drilling and blasting, the rocks are removed with hands and loaded into sacks that are carried to the surface through buckets pulled up by simple pulleys. Miners do not use any kind of personal protective equipment or gear.

The main objective of this study was to monitor health hazards and risk including effects of toxic gases and dust exposure during work processes at Merelani mine that are typical for small-scale mining in developing countries. The findings also present brief statistics of accidents from 1996-2002. 


\section{GENERAL GEOLOGY}

The Proterozoic (1900-700 Ma) lithostratigraphic units within the Mozambique Belt of Tanzania stretch in a $\mathrm{N}-\mathrm{S}$ direction east of the Tanzanian Craton and are known to host most of the coloured gemstones (Fig.1). This paper concentrates on the Merelani tanzanite mining area lying near the contact between the volcanic and the high-grade metamorphic rocks of the Mozambique Belt.

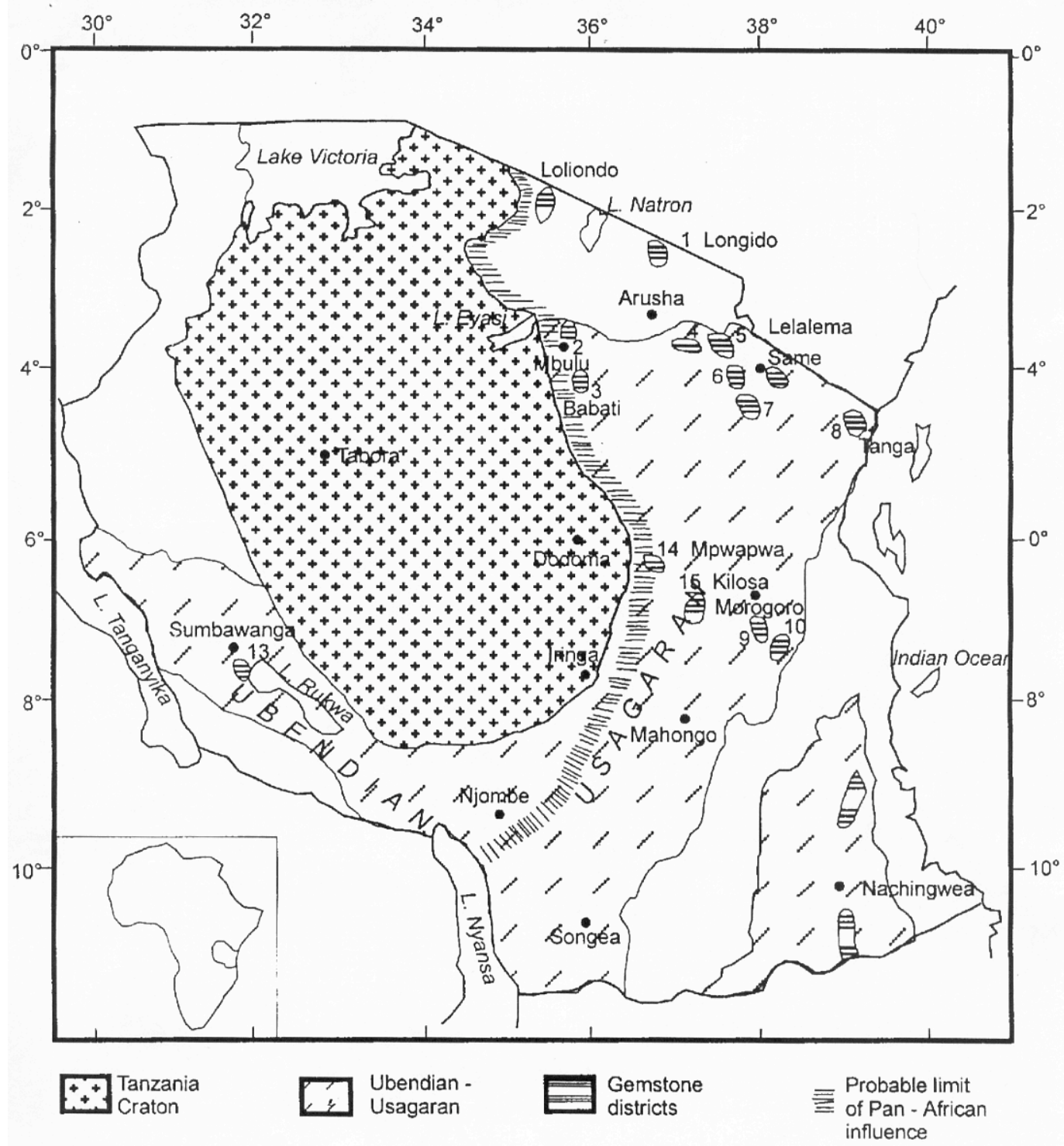

Figure 1: $\quad$ Sketch map showing gemstone mineralization in the Mozambique belt of Tanzania. 1) Longido, 2) Manyara, 3) Babati, 4) Merelani, 5) Lelatema, 6) Tiriri, 7) Landanai, 8) Umba, 9) Mvuha, 10) Magogoni, 11) Namaputa, 12) Nabunju, 13) Sumbawanga, 14) Mpwapwa, 15) Kilosa and 16) Loliondo (After Malisa and Muhongo 1990). 
The supracrustal rocks in the Merelani area are very similar to the rocks found elsewhere in the Mozambique Belt, consisting of psammitic, pelitic and psammo-pelitic gneisses, crystalline limestones, and to a lesser extent granite pegmatites and quartz veins. After the main phase of the Pan African tectonothemal event, these rocks have in some areas suffered alteration as reflected in their chemical and mineralogical composition as a result of the hydrothermal processes. The mineralization lies within the hydrothermally altered zone along the Lelatema fault zone with a northerly plunging regional scale fold structure. High quality blue zoisite (tanzanite) occurs in boudinaged quartz veins within the graphiterich hydrothermally altered gneisses. However, honey- yellow coloured with other colours may also be found outside the boudinaged structures. Inhalation of graphitic dust and silica particulates is the main problem miners face during extraction of the gems from the host rocks. Detailed studies on the geology of Merelani area is discussed by Malisa (1987) while the paragenesis of tanzanite, its crystallographic structure, mode of occurrence, the tectonic setting are described by Malisa and Koljonen (1986), Sundberg et al. (1988), Malisa and Muhongo (1990), respectively.

\section{METHODOLOGY}

Three one cubic meter glass containers opened on one side were used to collect dust in three selected mineshafts. The total dust collection was carried out during four consecutive days in the selected mine shafts. Sampling started before the miners entered the shafts and lasted until when they reappeared at the mine entrance after eight hours. The quartz content of the respirable dust samples was analysed by classical wet chemical method and graphite (C) with a Leco analyser (Carbon Determinator C12) in the chemical laboratories of the Geological Survey of Finland (GSF) in Espoo. The values obtained in the four sample containers were averaged for the silica and carbon.

\section{GEMSTONE MINING IN MERELANI Mining History}

The date of the first discovery of tanzanite is not exactly known. However, two prospectors, Mr. Manuel de Souza and Mr. Daudi Mayaya, have laid claim to the discovery at the Merelani area Saria (1973). It is without doubt that the Masai who live and graze cattle there showed the area to them. Private prospectors and local miners continued to mine from the time of discovery until 1971 when the government of Tanzania took over the administration of all mines. In 1971-1972, the Merelani mines operated under Tanzanian Gemstone Industries Ltd. (TGI), a subsidiary of the National Development Corporation (NDC). In 1972, the newly formed State Mining Corporation (STAMICO) took over the mines. Mining was done on small scale until recently when the government split the area into blocks of which block B and D were given to small-scale miners and Block $\mathrm{A}$ and $\mathrm{C}$ to large mining companies (Fig. 2). Large mining area which was been mined by the State Mining Company was given to a South African Company (AFGEM) who fenced it (see Fig. 3A) while the some artisanal miners have small plots around the fence (see Fig. 3B). 


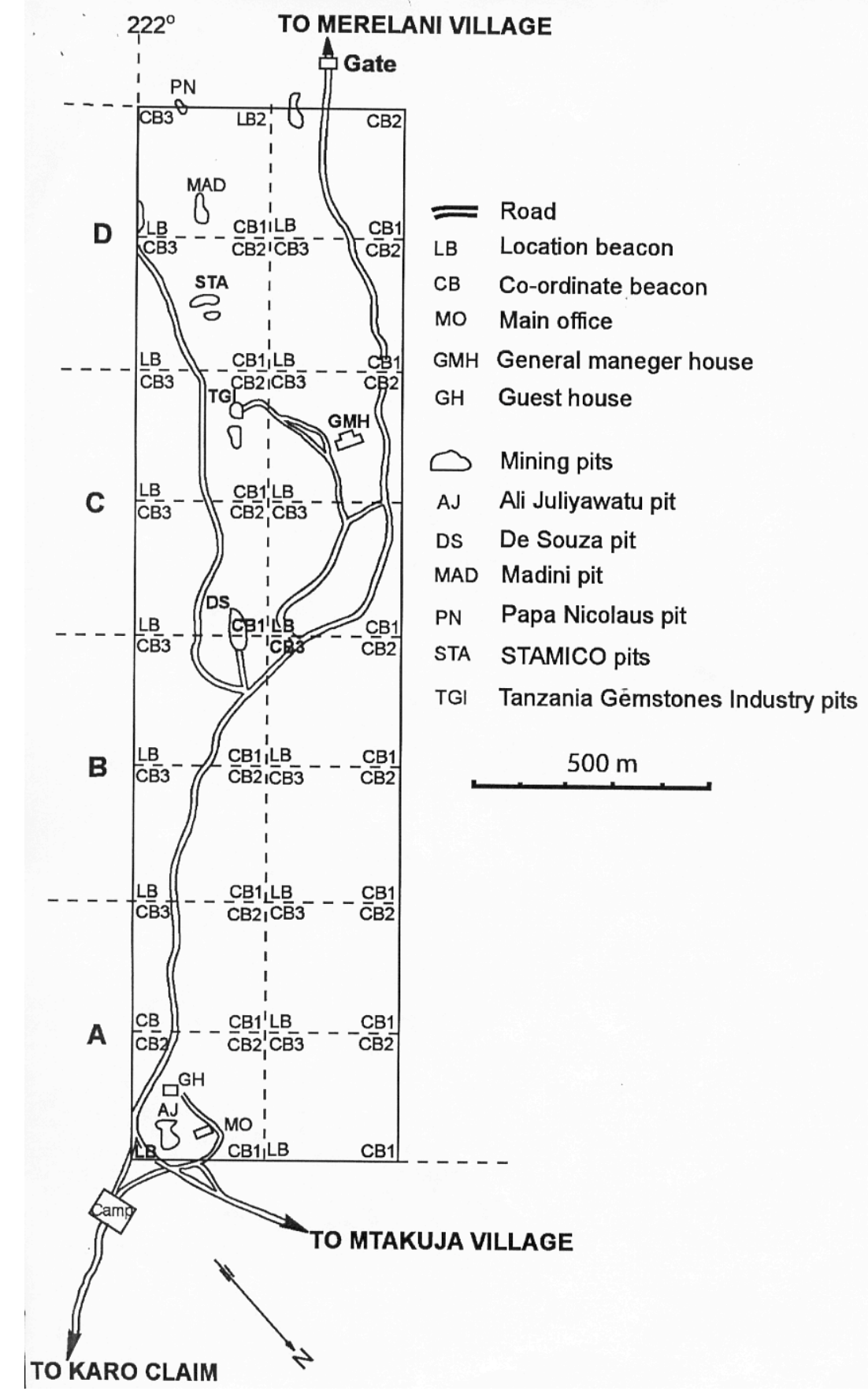

Figure 2: Tanzanite claims in the Merelani mining area, NE Tanzania (After Malisa 1987). 

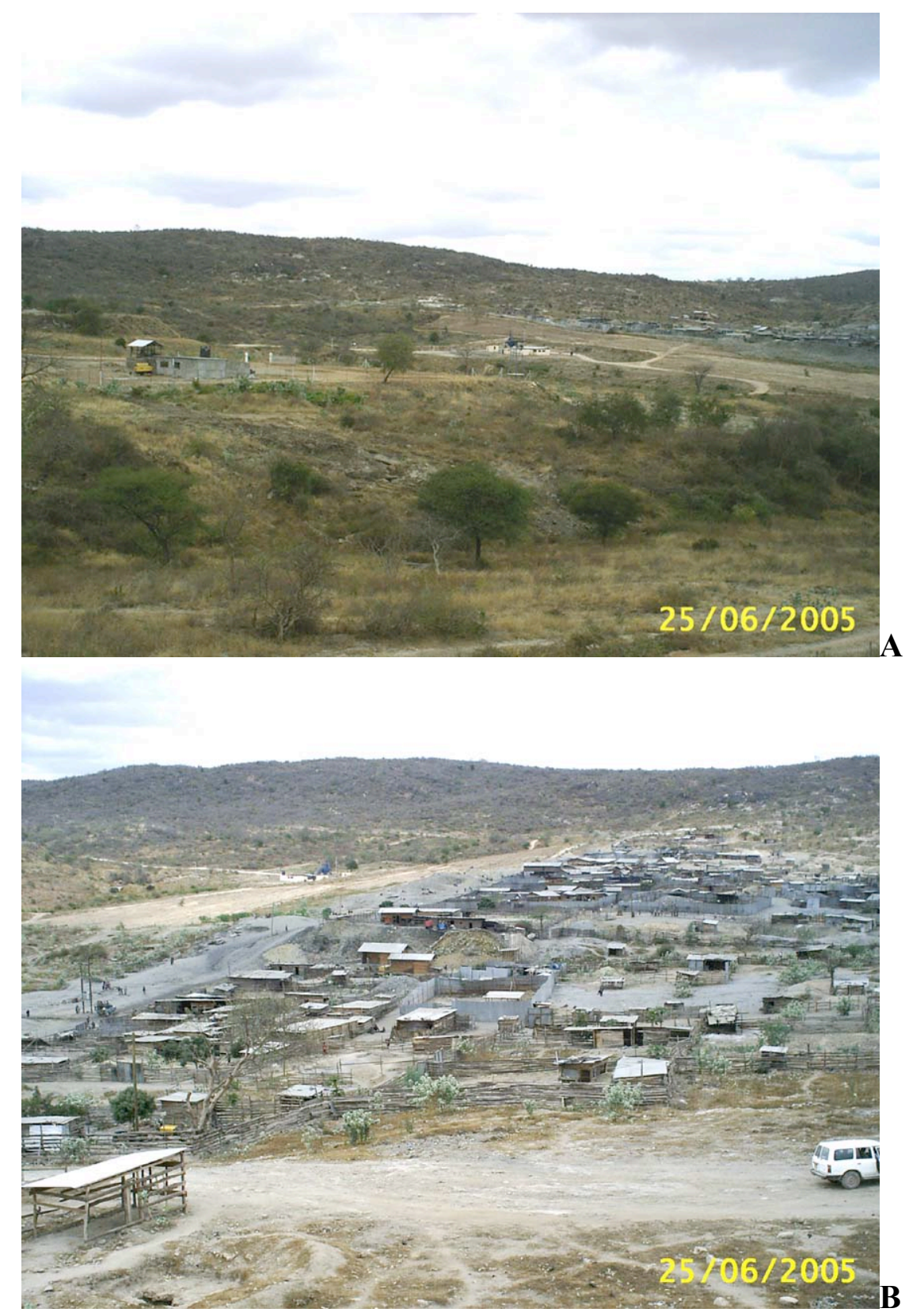

Figure 3: Photos showing A) Fenced claim of AFGEM with a patrol road around the fence. B) Local miners mining through the old mine tailings.

MAJOR PROBLEMS IN MERELANI MINE
The main handicap of Merelani mine is that mine owners invest minimal both in capital investment and mining costs but demand 
maximum outlay production. The mines have gone far deep beyond the capacity of shallow depth machines that were initially designed. As a result, the miner's work in an environment that deteriorates from day to day, working without safety gears or using worn out safety gears, narrow openings, poor ventilation and lighting, which limit miner's performance and render them prone to accidents. The common problems experienced are:

- Small size of mining plots which measure $50 \times 50 \mathrm{~m}$ and which may contain several deep shafts extending hundreds of meters;

- Inadequate working tools for the poor miners;

- Poor ventilation; $40 \%$ of accidents are due to poor ventilation resulting to suffocation during the period of 1996 to present;

- $\quad$ Poor mining methods used;

- $\quad$ Lack of safety tools and equipment;

- poor knowledge of economic and safe mining;

- $\quad$ Poor work contracts between employer and the miner;

- No mining inspection conducted as the shafts are unsafe for passage;

- Poor extension services - although the government is collecting revenues, miners have poor infrastructure;

- Environmental degradation;

- Extreme form of child labor, employing more than 2000 children in underground works; and

- Poor handling of hazardous chemicals and explosives;

However, in this paper emphasis will be on some social and occupational heath risks and hazards associated with mining operations.

\section{ENVIRONMENTAL ISSUES RELATED TO MERELANI MINES}

Child labor

In Merelani tanzanite mine, young boys compromise their physical and mental health by engaging themselves in exhausting work in deep and weakly constructed pits. Respiratory problems due to dust and harmful gases are exacerbated by poor ventilation. Child miners endure loud noise and excessive heat. They place themselves at further risk by remaining in mine shafts far below ground while explosives are detonated in hope of being the first to recover newly exposed tanzanite. Continuous monitoring of dust concentration should be constantly carried out as it can be linked with specific working operations and thus a reduction in exposure levels can be achieved.

Dust exposure and general working conditions in small-scale mining

The main objective of this study was to monitor dust exposure during work processes that are typical for small-scale mining in developing countries. A brief discussion of the general working conditions in the Merelani mine is also presented.

Sampling of respirable dust and total dust was carried out in three consecutive days in the selected mine. Sampling started immediately before the miners entered the shaft, and lasted until they reappeared at the mine entrance after 5-8 hours. The median of quartz and graphite content of the respirable dust samples were $13.6 \%$ and $5.5 \%$, respectively. When drilling, blasting and shovelling were carried out, the exposure measurements showed high median levels of overall respirable dust (15.5 $\mathrm{mg} / \mathrm{m} 3)$, respirable quartz $(2.4 \mathrm{mg} / \mathrm{m} 3)$, respirable graphite $(1.5 \mathrm{mg} / \mathrm{m} 3)$ and total dust $(28.4 \mathrm{mg} / \mathrm{m} 3)$. When only shovelling and loading of sacks took place, the median levels of overall respirable dust and quartz were $4.3 \mathrm{mg} / \mathrm{m} 3$ and $1.1 \mathrm{mg} / \mathrm{m} 3$. 


\section{Environmental aspects}

The environmental impact of Merelani mines can be attributed mostly to the simple technology and the lack of technical knowhow of most miners. The tools and extraction methods employed by small-scale miners are very basic. The rudimentary technology employed usually results in low rates of recovery that in turn leads to poor earnings and an inability of most miners to invest in appropriate technology. These results in a poor market, returns, working conditions, and a vicious cycle, which most miners find difficult to break. The mode of operation affects their ability and willingness to invest in proper mining methods. During the period of 1996-2002, a total of 17 people lost their lives due to collapse of hanging walls and 7 deaths caused by falling into a shaft, 3 deaths due to mine waste slide. The main cause was poor unplanned mining methods.

\section{Land degradation}

Most of the tanzanite mining activities are carried out underground, through deep shafts. As single licensed claim of 50x50 m is divided into small plots. During both shaft development and mining, a substantial amount of waste is excavated and piled in the vicinity of each shaft. The excavated shafts and piles of waste rock left behind after mining ceases have been identified as a severe, but localized, land degradation, which results in mine disasters e.g. flooding in wet season. In 1998, most mines in block B were flooded claiming more than 71 lives.
The excavated shaft and piles of waste rock also leads to accelerated erosion from both wind scour and surface runoff erosion. The topography of the area seems to determine the extent of the erosion. Poor ventilation after blasting is one of the major problems facing Merelani tanzanite mines.

\begin{abstract}
Air pollution
The impact of mining on air quality comes from the emission of dust, hydrocarbons and vapor during underground blasting. In almost all mining areas, dust is emitted into underground air polluting the working places. Underground drilling, ore loading, surface crushing and grinding, are all dry processes generating a lot of dust. Where jackhammers are in use for underground drilling, water is rarely used for dust suppression. Long exposure to any respirable dust is very dangerous to ones health. The exposure to graphite dust can cause serious lung diseases. In confined spaces like underground workings, this is a problem, as observed in many of the miners, which have black graphite complications after the underground works. Poor ventilation after blasting is one of the major problems facing Merelani mines. In 2002 more than 39 people lost their lives due to suffocation after blasting operations. The total number of people who suffocated in bocks B and D from 1996-2000 amounts to 86 deaths. Table 1 presents the amount of gases registered and Merelani mine as a consequence of blasting.
\end{abstract}

Table 1: The amount of gases registered at Merelani Mine as a consequence of blasting

\begin{tabular}{llll}
\hline & TWAEV $(\mathrm{ppm})$ & STEV $(\mathrm{ppm})$ & IDLH $(\mathrm{ppm})$ \\
\hline Ammonia & 25 & 35 & 300 \\
Carbon dioxide & 25 & 400 & 1200 \\
Nitric oxide & 25 & 100 & \\
Nitrogen dioxide & 3 & 5 & 20 \\
Sulfur dioxide & 2 & 5 & 100 \\
\hline
\end{tabular}

Noise and vibration pollution

The use of explosives in most mining areas is a major contributor to noise and vibrations. In confined areas with a large number of shafts, blasting is not coordinated such that blasts can be heard one after the 
other. This is the cause of many mining injuries and deaths among miners. Government regulations require explosives to be handled only by trained and licensed experts, but the regulations are not enforced although there is a code of practice in Swahili language approved by Ministry of Energy and Minerals for the miners. There were 13 deaths caused by explosion during blasting and 10 deaths from rock fragments flying from blasting.

\section{Other impacts}

The small-scale miners are also exposed to a large number of acute health risks. During recent years several fatal accidents in the Merelani mines have been caused by explosives, cave-ins, flooding etc. The number of of accidents for Blocks B and D are presented in Table 2 and 3 respectively. After flooding disasters in 1997 and 1998, which killed at least 200 miners, tripartite discussions resulted in an agreement on detailed health and safety rules. However, it appears that the majority of these rules are presently violated.

Table 2: $\quad$ Number of accidents at Block B, from 1996 to June 2002

\begin{tabular}{cccc}
\hline Year & Minor injuries & Major injuries & Fatal \\
\hline 1996 & 8 & 4 & 12 \\
1997 & 11 & 0 & 5 \\
1998 & 5 & 0 & 78 \\
1999 & 8 & 4 & 12 \\
2000 & 3 & 6 & 18 \\
2001 & 13 & 0 & 16 \\
2002 & 1 & 4 & 42 \\
Total & 49 & 18 & 183 \\
\hline
\end{tabular}

Table 3: $\quad$ The number of accidents at Block D, from 1996 to June 2002

\begin{tabular}{cccc}
\hline Year & Minor injuries & Major injuries & Fatal \\
\hline 1996 & 3 & 3 & 1 \\
1997 & 2 & 0 & 4 \\
1998 & 0 & 2 & 7 \\
1999 & 3 & 3 & 7 \\
2000 & 1 & 0 & 7 \\
2001 & 1 & 2 & 2 \\
2002 & 3 & 2 & 3 \\
Total & 13 & 12 & 31 \\
\hline
\end{tabular}

Other impacts resulting from artisanal-small scale tanzanite mining are those affecting the biological environment. As the number of miner's increases at a particular site, the demand for wood to construct shelters, support the shafts and provide energy for cooking increases tremendously. Consequently, the pressure on the surrounding forestry resources increases. In general, the use of timber for the mine support is normally negligible compared to those used in shelter construction and cooking. People clearing for agricultural activities clear large areas, whereas mining areas do not involve in clear-cutting. Other accidents caused by mechanical failure include 6 deaths due to breaking of hoisting cable and one death due to falling objects into the shaft. The summary of accident statistics is presented in Table 4. 
Table 4: $\quad$ Accident statistics from Merelani Mine, 1996 to June 2002

\begin{tabular}{lccc}
\hline Causes of accident & Block B & Block D & No. of deaths \\
\hline Suffocation & $87 \%$ & $13 \%$ & 86 \\
Explosion & $85 \%$ & $15 \%$ & 13 \\
Collapse of hanging wall & $47 \%$ & $53 \%$ & 17 \\
Rock fragments flying from blasting & $100 \%$ & $0 \%$ & 10 \\
Falling into shaft & $29 \%$ & $71 \%$ & 7 \\
Break of a hoisting cable & $100 \%$ & $0 \%$ & 6 \\
Flooding (El Nino floods) & $100 \%$ & $0 \%$ & 71 \\
Mine waste heap failure or slide & $0 \%$ & $100 \%$ & 3 \\
\hline
\end{tabular}

\section{HEALTH AND SAFETY IMPACTS}

The poor technology used in extraction of tanzanite, the inability to invest in safe working equipment and tools, the lack of technical know-how and the poor sanitary conditions in the mining camps, are some of the factors that threaten the miners health and safety

\section{Health impacts in mines}

Different studies have shown that the rate of mining accidents in the pits is low compared to the health hazards and illnesses occurring in the settlements (Phillips et al. 1997). Lack of adequate sanitation facilities and scarcity of water increase miner's health hazards.

Poor ventilation in deep underground pits leads to accidents due to lack of adequate air circulation. Poor circulation of fresh air leads to depletion of oxygen and the build up of other toxic gases. Suffocation from accumulation of toxic gases like carbon monoxide, hydrogen sulphide, sulphur dioxides and others, are common incidents. In areas where drilling is carried out using drilling equipment, e.g. jackhammers, there are rarely any measures to suppress the dust. In correct usage, drilling equipment for underground work is provided with a special connection for water that is used to suppress dust and for cooling. Most miners use machines designed for surface work underground, where ventilation is limited and thus are exposed to large amounts of dust. The dangers from dust exposure are made worse by the fact that miners usually lack protective gear, in this case, dust masks.

The introduction of mining equipment such as jackhammers, crushers and grinding mills without provision for protective gear is bound to have negative effects on the miner's health and safety. Apart from exposure to dust, which has been discussed above, noise from such equipment is a health hazard to their operators. Drillers in the underground pits usually work in very confined spaces without any ear protectors. Hearing problems are very common amongst underground drillers.

Loose morals and the spendthrift atmosphere in mining settlements make women vulnerable to sexual abuse, and communicable diseases, including sexually transmitted diseases spread easily. This has been found to affect mostly young girls and single women with no permanent attachments.

\section{Safety in mines}

Accidents in most working areas can be attributed to poor technology and lack of technical know-how. Lack of adequate scaffolding leads to accident from collapsing walls and tunnels.

Stabilizing the shafts requires engineering knowledge and the willingness and ability to take adequate measures. 
Lack of protective gear makes the miners more vulnerable to accidents. Most miners work barefoot, without gloves, safety belts, helmets and even adequate lighting for underground works. Domestic torches are commonly used for underground lighting with their batteries exposed openly. They provide inadequate light, and the used batteries are an environmental hazard, one of the known sources of mercury contamination.

Poor storage and negligence in handling explosives resulted in the death of two mine workers at Merelani in October 1999. Several nearby mines developed cracks and some collapsed.

\section{RECENT DISASTERS IN MERELANI}

Main poisoning gases at Merelani mine

The major poisoning gases in Merelani are:

- $\mathrm{CO}$ - carbon monoxide resulting from combustion of explosives

- $\mathrm{CO}_{2}$ - carbon dioxide resulting from combustion of explosives

- $\mathrm{H}_{2} \mathrm{~S}$ - hydrogen sulphide resulting from smelting of pyrite ore

- $\quad \mathrm{NO}, \mathrm{N}_{2} \mathrm{O}$ - nitrogen oxides from burned out explosives

- $\mathrm{HNO}_{2}$ and $\mathrm{HNO}_{3}$ resulting from reactions of nitrogen oxide gases with water

Other gases that may be produced during blasting include ammonia $\left(\mathrm{NH}_{3}\right)$, hydrogen sulfide $\left(\mathrm{H}_{2} \mathrm{~S}\right)$ and sulfur dioxide $\left(\mathrm{SO}_{2}\right)$.

\section{Flooding}

During the El Nino rains, all the mine-shafts in Merelani were flooded with mud, rock materials and water. Due to this, most shafts collapsed and most miners were trapped in the mines.

\section{Mechanical failures}

Major mechanical failures include:

- Collapse of hanging wall

- $\quad$ Rock fragments from blasting

- Failing shafts

\section{RECOMMENDATIONS Blasting operations}

After blasting in underground mines, there should be minimum requirements for conducting examinations on the safety of human beings due to gases emitted. This is called gas check in underground mines. During the gas check operations one should include the following points. Because of variations in mine design and blasting procedure, this checklist does not attempt to identify testing locations, timing, or other points that are specific to each mine.

Identify competent person in charge - The procedure should identify the supervisor in charge of post-blast examinations.

Identify trained or qualified personnel for performing examinations. Employees performing post-blast examinations should have received training and displayed competency that meets requirements of legislation and mining policy in the following areas:

- Use of gas testing equipment

- Use of personal protective equipment

- Communication procedures

- Ventilation procedures

The specific gases to be measured will be determined by the experience of the mine. Most mines test for carbon monoxide, (CO), carbon dioxide $\mathrm{CO}_{2}$ and nitrogen dioxide $\left(\mathrm{NO}_{2}\right)$. It may be possible for a mine to use a single gas as an "indicator" where experience has shown that other potential contaminants have also been reduced to acceptable concentrations once the indicator gas has been diluted by the ventilation system. Oxygen concentration may also be measured during clearance testing especially if an electronic meter is used for the measurement.

Gas testers can either use remote monitors, either fixed or portable, to measure concentrations of the toxic gasses emitted during blasting or they can use detector tubes. In any case, the instrument must be 
prepared and calibrated well e.g. ensuring the batteries are charged (or fresh), ensuring the sensor(s) has not expired, removing all plugs, caps or other storage materials, ensuring the instrument has been calibrated within the required period, zeroing the instrument in fresh air, performing field tests to ensure light, alarms or other features of the instrument are functioning.

Personal protective equipment has to be worn by the gas testing team. It should also state whether this equipment should be worn or simply carried for possible use.

Communication equipment to be used by gas testing team is essential and careful identification of the kind of communication equipment that would be appropriate should be made.

All the necessary information e.g. communication of blast locations and area to be inspected for gases, has to be familiar to testing team. Normal ventilation procedure and the conditions expected after the blast should also be conveyed to the team.

The gas checking team has to identify the procedure that is to be performed in order to restore normal ventilation conditions. These instructions will vary depending on the location and the size of the blast(s).

The team has the task of identification and reporting the blast damage. They should be capable of identifying what damage from the blast are to be reported e.g. damaged doors and bulkheads, falls of ground. They should also identify what repairs are to be made and include steps for stopping the examination process if the ground conditions are considered unsafe.

Permissible concentrations of gases should be clearly established by existing regulations. The limits for gases normally encountered as a consequence of blasting are:
- The Time-Weighted Average Exposure Value (TWAEV) is the maximum average airborne concentration of a contaminant that a worker may be exposed to for an eight-hour day and 40hour week.

- The short-term Exposure Value (STEV) is the maximum airborne concentration of a contaminant that a worker may be exposed to in any 15-minute period. (Note: The status of the STEV for carbon monoxide is uncertain.)

An Immediately Dangerous to Life and Health (IDLH) condition is defined as one "that poses a threat of exposure to airborne contaminants when that exposure is likely to cause death or immediate or delayed permanent adverse health effects to prevent escape from such an environment."

These exposure limits may change and firms should ensure that the current values are being used.

\section{Use of mine collars}

Strong cemented foundation is required which direct runoff during heavy rains.

Construction of drainage canals to direct water during heavy rains

\section{Reinforcement of shafts}

Reduce mechanical failures by using proper timbering of shaft walls.

Miners have to use protective gears e.g. helmets to protect from flying rock fragments during blasting.

\section{RECORDED ACCIDENTS}

There have been a number of accidents in Merelani area. The following are the recorded accidents in the different blocks.

Major fatal accidents registered were 39 deaths at Block B, on 19 June 2002. The shaft extended to a depth of $90 \mathrm{~m}$ with a horizontal extension of $147 \mathrm{~m}$., which is 3 times the length of claim size issued by the responsible ministry. 


\section{DISCUSSIONS AND CONCLUSIONS}

The Merelani tanzanite mining area is a local village that is growing up around informal workings; getting crowded, crime-ridden thus unsanitary and the mining operations themselves tend to be inefficient, unsafe, and environmentally damaging. The miners especially the youngsters are also exposed to a number of acute communicable diseases including sexually transmitted diseases, typhoid and malaria. Proper management and safety policies must be introduced while discouraging the primitive mining operations.

In conclusion, in the absence of personal protective equipment, the exposure to high levels of quartz poses a serious risk of developing chronic silicosis for the numerous underground miners in Merelani. Moreover, our observations confirm several of the health and safety problems described in the 1999 ILO-report "Social and labour issues in small-scale mines".

\section{REFERENCES}

ILO, Sectorial activities Progrmme 1999 Social and labour issues in smallscale mines. Report for discussion and the Tripartite Meeting on Social and Labour issues in small-scale mines, Geneva.

Malisa E and Koljonen T 1986 Paragenesis of tanzanite (zoisite) in the Merelani area, NE Tanzania. Poster presentation. Poster Abstracts, 7th
International Association on the Ore Deposits. Symposium Nodkalott Poject Meeting, 18-22nd August, Lulea, Sweden.

Malisa E 1987 Geology of the tanzanite gemstone deposits in the Lelatema area, NE Tanzania. Ph.D. thesis. Ann. Acad. Sci. Fenn. III. Geologica-Geographica 146, 160 p. with 3 appendix maps

Malisa E and Muhongo S 1990 Tectonic setting of gemstone mineralization in the Proterozoic metamorphic terrain of the Mozambique belt in Tanzania. Precambrian Res. 46: 167-176

Phillips LC, Semboja H, Shukla GP, Sezinga R, Mutagwaba W, Mchwampaka B, Wanga C, Kahyrara $\mathrm{O}$ and Keller P 2001 Tanzanias Precious Metals Boom. Issues in Mining and Marketing. Research Paper 2001. USAID AFRSD SA (4.06-115). Washington D.C.

Saria JL 1973 The geology of the Merelani zoisite (tanzanite) bearing area. Unpubl. Rep., Geol. Surv. Tanzania, Miner. Resour. Div., Dodoma, Rep. JLS/7, 9p.

Sunderg M, Valkonen J, Kiveka R, Koljonen T and Malisa E 1988 Refinement of the structure of heate (blue) form of zoisite (tanzanite). Zeitschrift fur Kristallographie 185(1-4): 617 